\title{
Sensory Characteristic of Gluten-Free Popular Indonesian Cookies
}

\author{
Andian Ari Anggraeni, Titin Hera Widi Handayani, Sri Palupi \\ Faculty of Engineering, Universitas Negeri Yogyakarta \\ Yogyakarta, Indonesia \\ andian_ari@uny.ac.id, titin_hwh@uny.ac.id,sripalupi5@yahoo.co.id
}

\begin{abstract}
This research was performed to develop glutenfree cookies using modified cassava flour-based composite flour. Cookies popular in Indonesia, such as choco-chips, nastar, and kastengel cookies, were produced from various blends of modified cassava flour (MCF), rice flour (RF), maize flour (MF), isolated soy protein (ISP), xanthan gum (XG) and/or guar gum (GG). Cookies were subjected to sensory evaluation to analyze color, flavor, texture, taste and overall acceptability. Sensory evaluation was performed by trained panelist. The blend of MCF $\mathbf{8 0 \%}$ and RF $20 \%$ resulted in the most acceptable sensory characteristic (texture, taste, and overall acceptability) among all of the gluten-free choco-chips cookies. Nastar cookies made from MCF $85 \%$, MZ 10\%, ISP 5\% and XG $2 \%$ flour based was the most acceptable in sensory characteristic (color, texture, taste), whereas nastar cookies made from MCF 85\%, RF 10\%, ISP 5\% and XG $2 \%$ flour based was acceptable (color, texture, taste) and economical. Nastar cookies produced from the blend of MCF $75 \%$, RF $20 \%$, ISP $5 \%$ and XG $2 \%$ flour based showed the most sensory acceptability in overall acceptance. Kastengel cookies produced from the blend of MCF $85 \%$, MZ 10\%, ISP $5 \%$ and XG $2 \%$ resulted in higher sensory characteristic (color, flavor, taste and overall acceptability) than other gluten-free kastengel cookies.
\end{abstract}

Keywords-cookies; choco-chips; nastar; kastengel; modified cassava flour; gluten-free

\section{INTRODUCTION}

Recently, the bakery industry in Indonesia is growing very fast. The bakery product becomes popular among people of all age group. Among the bakery products, cookies own several interesting characteristics, such as good eating quality, availability, long shelf-life and ready-to-eat convenience [1].

The main ingredient of cookie is soft wheat. Cookies are made from the blend of various ingredients such as flour, fat, sweetener, and water [2]. Most of cookie formula contains less liquid than cake formula so that it prevents the development of gluten during mixing. The cookie dough is not allowed to ferment. Cookie dough ranges from soft to very stiff. Unlike cake, the cookie dough is individually shaped or formed. There are several types of cookie make-up, such as bagged, dropped, rolled, molded, ice box, bar, sheet, and stencil. It is essential to shape cookie to uniform size and shape. Cookies are baked and dried to very low moisture.

Cookie has several characteristics, such as size, shape, flavor, and texture. Cookie characteristic may differ from one to another, from small to big, from sweet to salty and from crisp to soft or chewy. Cookie crispness depends on low liquid ingredient, high sugar and fat content, long baking time, small or thin shape, and proper storage in air-tight container. Cookie softness is the opposite of crispness. Cookie chewiness depends on high sugar, liquid, and egg content, low-fat content, and gluten development during mixing. Cookie spread related to high sugar content, high baking soda content, the light creaming of fat and sugar, no activation of gluten during mixing, baking on a heavily greased pan, and low baking temperature [3].

There are several kinds of cookies popular in Indonesia which are commonly made from wheat flour, such as chocochips cookies, nastar cookies, and kastengel cookies. Chocochips cookies are dropped cookies, with the characteristic of brown in color, crisp, and sweet. Nastar cookies are molded cookies. Nastar cookies are formed to round-ball shape, contains pineapple jam in the center of the cookie. Nastar cookies have sour and sweet taste, golden yellow color, and smooth texture. Kastengel cookies are rolled cookies. The kastengel dough contains edam cheese, so that it is salty, golden yellow in color, and smooth. It is desired that both nastar and kastengel cookies are melted in the mouth.

Due to the fast growing of bakery product, the demand for imported wheat in Indonesia raise significantly. This problem threatens Indonesia's food security. To encourage food security, the government of Indonesia supports the intensification of locally grown crops production and food diversification. Cookies which are commonly made from wheat flour are encouraged to substitute with locally-growncrop flour. The use of gluten-free composite flour in cookies is expected to meet customer acceptance in sensory characteristic.

Cassava (Manihot esculenta) is a staple food locally grown in Indonesia. But cassava is less popular than rice, wheat, and corn. Cassava is drought resistant and pest attack tolerant. It is able to produce acceptable yield on critical conditions of water and soil nutrition [4]. As the result of government's program on the intensification of locally-grown crop, cassava production in Indonesia has risen from 17,2 million in 1993 to 23,4 million in 2014 [5]. Cassava can be transformed to produce cassava starch flour and modified cassava flour (mocaf). The sensory characteristic of mocaf is alike wheat flour, such as white, soft and cassava odorless). Mocaf is also the same price with wheat flour. 
The formulation of cookies made from mocaf has not yet developed. The objective of this research was to develop choco-chips, nastar and kastengel cookie from mocaf or mocaf-based composite flour. The sensory evaluation of these gluten-free cookies was determined.

\section{MATERIALS AND METHODS}

\section{A. Materials}

Materials used for choco-chips cookies preparation were wheat (Triticum aestivum) flour (WF), mocaf (MCF), rice (Oryza sativa) flour (RF), maize flour (MF), margarine, butter, powder sugar, egg yolk, dark chocolate compound, powder chocolate, and choco chips. Nastar cookies were prepared from mocaf (MCF), rice flour (RF), maize flour (MF), isolated soy protein (ISP), xanthan gum (XG), margarine, butter, powder sugar, egg yolk, dry milk, pineapple, sugar, cinnamon, and clove. Kastengel cookies were made from wheat flour (WF), mocaf (MCF), maize flour (MF), isolated soy protein (ISP), guar gum (GG), xanthan gum (XG), margarine, butter, egg yolk, edam cheese and cheddar cheese.

Mocaf was purchased from Putri 21, Gunung Kidul, Yogyakarta. Isolated soy protein was purchased from Shandong Crown Soya Protein Co. Ltd. Guar gum was procured from Hindustan Gum \& Chemicals Limited. Xanthan gum was bought from CV. Nura Jaya. And other materials were purchased from commercial brands in the local supermarket of Yogyakarta.

\section{B. Choco-chips Cookies Preparation}

Margarine, butter, powder sugar and egg yolk were mixed until light, fluffy and creamy. Wheat flour / mocaf / rice flour / maize flour were roasted until slight brown. Wheat flour / mocaf / rice flour / maize flour were added to the creamy dough and blended well. Then dark chocolate compound and powder chocolate were added and mixed until a stiff paste batter was obtained. Around 12 grams batter was dropped by spoon and set around $4,5 \mathrm{~cm}$ in diameter. Choco-chips were placed on the top surface of the dough. The batter was baked at $160{ }^{\circ} \mathrm{C}$ for 16 to 23 minutes.

\section{Nastar Cookies Preparation}

Pineapple jam was prepared first. One piece of pineapple was grated, and then mixed with 100 gram sugar, $2 \mathrm{~cm}$ cinnamon and 2 pcs clove. The mixture was boiled until the texture become thick and then put aside. Margarine, butter, egg yolk, powder sugar and dry milk were mixed until smooth and white color. Mocaf, rice flour, maize flour, isolated soy protein, and xanthan gum were added to the cream dough and blended well. Around 8 grams batter was weighed and flattened. Pineapple jam was placed in the center of the batter and then shaped into round ball. The oven was set at $155^{\circ} \mathrm{C}$ at the top and $160{ }^{\circ} \mathrm{C}$ at the bottom and the dough was baked for 38 to 40 minutes.

\section{Kastengel Cookies Preparation}

Margarine and butter were mixed until smooth. Egg yolk was added to the fat mixture and then blended well. Grated edam cheese was added and mixed well. Wheat flour / mocaf / maize flour, isolated soy protein, xanthan gum / guar gum were added and mixed well until the batter became stiff. The batter was rolled using a rolling pin, mold with kastengel mold and put on the baking tray. The molding batter was brushed with egg yolk. Grated cheddar cheese was put on the top surface of the cookie. Oven temperature was set to be $165^{\circ} \mathrm{C}$ at the top and $160{ }^{\circ} \mathrm{C}$ at the bottom and cookies were baked for $25-37$ minutes.

\section{E. Sensory Evaluation}

The well-baked cookies were cooled to room temperature and stored in low-density poly ethylene (LDPE) pouches inside air tight container. Cookies samples were subjected to sensory evaluation after 24 hours. The sensory characteristics of cookies were evaluated using hedonic scale test by 4 to 6 trained panelists. The panelists were asked to evaluate sensory characteristics such as color, flavor, texture, taste, and overall acceptability. The panelists were asked to evaluate the sensory characteristics using 9-Point Hedonic Score System. The panelist marks the cookies from 9 to 1, ranging from 'like extremely' to 'disliked extremely' to determine the most acceptable composition of cookies. Cookies samples were randomly ordered and placed in coded LDPE pouches. Tap water was prepared to clean the mouth between the evaluation.

\section{F. Statistic}

The results of sensory evaluation were subjected to analysis of variance (ANOVA). The significance of difference between the average values was evaluated using Duncan comparison test $(\mathrm{P} \leq 5 \%)$.

\section{RESULTS AND DISCUSSION}

\section{A. Sensory Evaluation of Chocho-chips Cookies}

Choco-chips cookies were prepared from different blends of flour. The difference of the formulation of choco-chips cookies was shown in TABLE I.

TABLE I. CHOCO-CHIPS COOKIES INGREDIENTS

\begin{tabular}{|l|r|r|r|r|r|r|}
\hline \multicolumn{1}{|c|}{ Ingredients } & \multicolumn{1}{c|}{ A } & \multicolumn{1}{c|}{ B } & \multicolumn{1}{c|}{ C } & \multicolumn{1}{c|}{ D } & \multicolumn{1}{c|}{ E } & \multicolumn{1}{c|}{ F } \\
\hline Wheat flour, g & - & - & - & - & - & 100 \\
\hline Mocaf, g & 100 & 90 & 80 & 80 & 70 & - \\
\hline Rice flour, g & - & 10 & 20 & 10 & 30 & - \\
\hline Maize flour, g & - & - & - & 10 & - & - \\
\hline Margarine, g & 50 & 50 & 50 & 50 & 50 & 50 \\
\hline Butter, g & 25 & 25 & 25 & 25 & 25 & 25 \\
\hline Powder sugar, g & 50 & 50 & 50 & 50 & 50 & 50 \\
\hline Egg yolk, g & 17 & 17 & 17 & 17 & 17 & 17 \\
\hline Dark chocolate compound, g & 25 & 25 & 25 & 25 & 25 & 25 \\
\hline Powder chocolate, g & 5 & 5 & 5 & 5 & 5 & 5 \\
\hline Choco-chips, g & 8 & 8 & 8 & 8 & 8 & 8 \\
\hline & & & & & & \\
\hline Baking time, min & 23 & 23 & 23 & 23 & 23 & 16 \\
\hline
\end{tabular}

Sample A had $100 \%$ MCF. Sample B consisted of $90 \%$ MCF and 10\% RF. Sample C contained $80 \%$ MCF and $20 \%$ RF. Sample D had the composition of $80 \% \mathrm{MCF}, 10 \% \mathrm{RF}$ and $10 \%$ MF. Sample E contained 70\% MCF and 30\% RF. Sample F made from $100 \% \mathrm{WF}$.

TABLE II showed the sensory evaluation of choco-chips cookies. Sample F (100\% WF) had the highest overall acceptability of 7.7, and sample A (100\% MCF) showed the lowest overall acceptability of 7.0. The wheat flour control (F) had the highest sensory characteristic (color, flavor, texture, 
taste and overall acceptability) among all of the samples. Whereas sample A (100\% MCF) showed the lowest sensory characteristic in color, flavor, texture, taste and overall acceptability. Among all of the gluten-free samples, sample $\mathrm{C}$ (80\% MCF, 20\% RF) showed the highest values in texture, taste and overall acceptability.

TABLE II. SENSORY EVALUATION OF CHOCO-CHIPS COOKIES

\begin{tabular}{|l|r|r|r|r|r|}
\hline Sample & Color & Flavor & Texture & \multicolumn{1}{c|}{ Taste } & $\begin{array}{c}\text { Overall } \\
\text { Acceptability }\end{array}$ \\
\hline A & $8.0^{\mathrm{a}}$ & $7.2^{\mathrm{a}}$ & $6.7^{\mathrm{a}}$ & $6.8^{\mathrm{a}}$ & $7.0^{\mathrm{a}}$ \\
\hline B & $7.2^{\mathrm{b}}$ & $7.2^{\mathrm{a}}$ & $7.2^{\mathrm{a}}$ & $7.7^{\mathrm{a}}$ & $7.2^{\mathrm{a}}$ \\
\hline C & $6.7^{\mathrm{b}}$ & $7.3^{\mathrm{a}}$ & $7.5^{\mathrm{a}}$ & $7.8^{\mathrm{a}}$ & $7.6^{\mathrm{a}}$ \\
\hline D & $7.0^{\mathrm{b}}$ & $7.5^{\mathrm{a}}$ & $7.3^{\mathrm{a}}$ & $7.3^{\mathrm{a}}$ & $7.4^{\mathrm{a}}$ \\
\hline E & $7.3^{\mathrm{a}}$ & $7.3^{\mathrm{a}}$ & $7.3^{\mathrm{a}}$ & $7.2^{\mathrm{a}}$ & $7.2^{\mathrm{a}}$ \\
\hline F & $8.2^{\mathrm{a}}$ & $7.7^{\mathrm{a}}$ & $7.8^{\mathrm{a}}$ & $8.0^{\mathrm{a}}$ & $7.7^{\mathrm{a}}$ \\
\hline
\end{tabular}

Sensory evaluation by 6 trained panelists. Columns with the same superscripts are not significantly different at $\mathrm{P} \leq 0.05$

The result of this study also indicated that the total substitution of wheat flour to mocaf resulted in the least acceptable sensory characteristic. The incorporation of rice flour was proved to increase the sensory characteristic. The blend of mocaf and rice flour is encouraging in the production of gluten-free choco-chips cookies.

Gluten-free cookies formulation without any improver (isolated soy protein and hydrocolloids) were reported to increase the cookies hardness significantly $[6,7]$. The result of this research also showed that the absence of improver (isolated soy protein and hydrocolloids such as xanthan gum or guar gum) resulted in cookies having less sensory characteristic in texture than wheat-flour cookies.

\section{B. Sensory Evaluation of Nastar Cookies}

Several blends of flour, isolated soy protein, and xanthan gum were prepared to make nastar cookies. The ingredients used in the preparation of nastar cookies were shown in TABLE III.

Sample G contained $100 \%$ MCF. Sample H consisted of MCF $95 \%$, ISP 5\% and XG 2\% flour based. Sample I contained MCF 85\%, RF 10\%, ISP 5\% and XG 2\% flour based. Sample J had the composition of MCF $85 \%$, MZ $10 \%$, ISP $5 \%$ and XG 2\% flour based. Sample K consisted of MCF $75 \%$, RF $20 \%$, ISP $5 \%$ and XG 2\% flour based.

TABLE III. NASTAR COOKIES INGREDIENTS

\begin{tabular}{|l|r|r|r|r|r|}
\hline \multicolumn{1}{|c|}{ Ingredients } & \multicolumn{1}{c|}{ G } & \multicolumn{1}{c|}{ H } & \multicolumn{1}{c|}{ I } & \multicolumn{1}{c|}{ J } & \multicolumn{1}{c|}{ K } \\
\hline Mocaf, g & 100.0 & 95.0 & 85.0 & 85.0 & 75.0 \\
\hline Rice flour, g & - & - & 10.0 & - & 20.0 \\
\hline Maize flour, g & - & - & - & 10.0 & - \\
\hline Isolated soy protein, g & - & 5.0 & 5.0 & 5.0 & 5.0 \\
\hline Xanthan gum, g & - & 2.0 & 2.0 & 2.0 & 2.0 \\
\hline Margarine, g & 48.0 & 48.0 & 48.0 & 48.0 & 48.0 \\
\hline Butter, g & 25.0 & 25.0 & 25.0 & 25.0 & 25.0 \\
\hline Powder sugar, g & 18.0 & 18.0 & 18.0 & 18.0 & 18.0 \\
\hline Egg yolk, g & 17.0 & 17.0 & 17.0 & 17.0 & 17.0 \\
\hline Dry milk, g & 3.6 & 3.6 & 3.6 & 3.6 & 3.6 \\
\hline & & & & & \\
\hline Baking time, min & 40 & 40 & 38 & 38 & 38 \\
\hline
\end{tabular}

The sensory evaluation of nastar cookies was shown in TABLE IV. Sample G had the lowest overall acceptability of 6.5 . The study revealed that the use of $100 \%$ mocaf resulted in cookies having the lowest sensory acceptability. Because of that, the use of composite flour was suggested to produce naster cookies with better consumer acceptance. All of the sample H, I, J and K were blended from various flour. Sample $\mathrm{K}$ showed the highest overall acceptability of 8.0 and flavor of 8.5. Sample $\mathrm{J}$ showed the highest sensory characteristic in color, texture, and taste. The sensory characteristic of nastar cookies showed no significant difference $(\mathrm{P} \leq 5 \%)$, between sample I, J and K.

TABLE IV. SENSORY EVALUATION OF NASTAR COOKIES

\begin{tabular}{|l|r|r|r|r|r|}
\hline Sample & Color & Flavor & Texture & Taste & $\begin{array}{c}\text { Overall } \\
\text { Acceptability }\end{array}$ \\
\hline $\mathrm{G}$ & $5.8^{\mathrm{b}}$ & $7.3^{\mathrm{a}}$ & $6.0^{\mathrm{b}}$ & $7.0^{\mathrm{a}}$ & $6.5^{\mathrm{b}}$ \\
\hline $\mathrm{H}$ & $6.3^{\mathrm{b}}$ & $7.8^{\mathrm{a}}$ & $7.3^{\mathrm{a}}$ & $7.3^{\mathrm{a}}$ & $7.3^{\mathrm{ab}}$ \\
\hline $\mathrm{I}$ & $7.3^{\mathrm{a}}$ & $7.8^{\mathrm{a}}$ & $7.8^{\mathrm{a}}$ & $7.8^{\mathrm{a}}$ & $7.3^{\mathrm{ab}}$ \\
\hline $\mathrm{J}$ & $8.0^{\mathrm{a}}$ & $7.8^{\mathrm{a}}$ & $7.8^{\mathrm{a}}$ & $8.0^{\mathrm{a}}$ & $7.5^{\mathrm{a}}$ \\
\hline $\mathrm{K}$ & $7.8^{\mathrm{a}}$ & $8.5^{\mathrm{a}}$ & $7.5^{\mathrm{a}}$ & $7.8^{\mathrm{a}}$ & $8.0^{\mathrm{a}}$ \\
\hline
\end{tabular}
significantly different at $\mathrm{P} \leq 0.05$

Nastar cookie is desired to be melted in the mouth, because of that the texture of the nastar cookie plays important role in the sensory characteristic of nastar cookie. Sample I and J has the same score on texture of 7.8. The difference between the composition of sample I and $\mathbf{J}$ were the use of rice flour and maize flour, in sample $I$ and $J$ respectively. However, the sensory characteristic of sample I and $\mathrm{J}$ were not significantly different $(\mathrm{P}>0.05)$, especially in color, flavor, texture, and taste. The price of maize flour is 2.5 times more expensive than rice flour. Because of that, sample $\mathrm{I}$ is more economical than sample $\mathbf{J}$ to produce nastar cookie.

Based on the sensory evaluation, the blend of MCF $75 \%$, RF 20\%, ISP 5\% and XG 2\% flour based resulted in the most acceptance in overall acceptability.

\section{Sensory Evaluation of Kastengel Cookies}

Kastengel cookies were made from various blends of flour, isolated soy protein and hydrocolloids (xanthan gum or guar gum). The compositions of kastengel cookies were shown in TABLE V.

TABLE V. KASTENGEL COOKIES INGREDIENTS

\begin{tabular}{|l|r|r|r|r|r|}
\hline \multicolumn{1}{|c|}{ Ingredients } & \multicolumn{1}{c|}{ K1 } & \multicolumn{1}{c|}{ K2 } & \multicolumn{1}{c|}{ K3 } & \multicolumn{1}{c|}{ K4 } & \multicolumn{1}{c|}{ K5 } \\
\hline Wheat flour, g & 100.0 & - & - & - & - \\
\hline Mocaf, g & - & 100.0 & 85.0 & 85.0 & 85.0 \\
\hline Maize flour, g & - & - & 10.0 & 10.0 & 10.0 \\
\hline Isolated soy protein, g & - & - & 5.0 & 5.0 & 5.0 \\
\hline Xanthan gum, g & - & - & - & 2.0 & - \\
\hline Guar gum, g & - & - & - & - & 2.0 \\
\hline Margarine, g & 63.0 & 63.0 & 63.0 & 63.0 & 63.0 \\
\hline Butter, g & 25.0 & 25.0 & 25.0 & 25.0 & 25.0 \\
\hline Egg yolk, g & 9.0 & 9.0 & 9.0 & 9.0 & 9.0 \\
\hline Edam cheese, g & 37.0 & 37.0 & 37.0 & 37.0 & 37.0 \\
\hline Cheddar cheese, g & 13.0 & 13.0 & 13.0 & 13.0 & 13.0 \\
\hline & & & & & \\
\hline Baking time, min & 25 & 37 & 35 & 35 & 35 \\
\hline
\end{tabular}


Sample K1 contained $100 \%$ WF. Sample K2 consisted of $100 \%$ MCF. Sample K3 has the composition of $85 \%$ MCF, $10 \% \mathrm{MZ}$, and $5 \%$ ISP. Sample K4 consisted of $85 \% \mathrm{MCF}$, $10 \% \mathrm{MZ}, 5 \%$ ISP and $2 \% \mathrm{XG}$ flour based. Sample K5 contained $85 \% \mathrm{MCF}, 10 \% \mathrm{MZ}, 5 \%$ ISP and 2\% GG flour based.

TABLE VI showed the sensory evaluation of kastengel cookies. Sample K1 had the highest sensory characteristic in color, taste and overall acceptability. Sample K2 showed the lowest sensory characteristic in color, taste and overall acceptability. This result indicated that the total substitution of wheat flour to mocaf resulted in less acceptable sensory characteristic of kastengel cookies. The use of composite flour was recommended to improve the sensory characteristic of kastengel cookies made from $100 \%$ mocaf. Sample K3, K4, and $\mathrm{K} 5$ were composite flour blended from various flour and improver.

TABLE VI. SENSORY EVALUATION OF KASTENGEL COOKIES

\begin{tabular}{|l|r|r|r|r|r|}
\hline Sample & Color & Flavor & Texture & Taste & $\begin{array}{c}\text { Overall } \\
\text { Acceptability }\end{array}$ \\
\hline K1 & $8.5^{\mathrm{a}}$ & $7.5^{\mathrm{a}}$ & $7.5^{\mathrm{a}}$ & $7.7^{\mathrm{a}}$ & $8.0^{\mathrm{a}}$ \\
\hline $\mathrm{K} 2$ & $6.5^{\mathrm{b}}$ & $7.3^{\mathrm{a}}$ & $8.0^{\mathrm{a}}$ & $6.7^{\mathrm{a}}$ & $7.0^{\mathrm{a}}$ \\
\hline $\mathrm{K} 3$ & $7.5^{\mathrm{ab}}$ & $7.5^{\mathrm{a}}$ & $8.2^{\mathrm{a}}$ & $7.3^{\mathrm{a}}$ & $7.3^{\mathrm{a}}$ \\
\hline $\mathrm{K} 4$ & $8.0^{\mathrm{a}}$ & $7.7^{\mathrm{a}}$ & $7.8^{\mathrm{a}}$ & $7.5^{\mathrm{a}}$ & $8.0^{\mathrm{a}}$ \\
\hline $\mathrm{K} 5$ & $7.5^{\mathrm{ab}}$ & $6.5^{\mathrm{a}}$ & $8.0^{\mathrm{a}}$ & $6.7^{\mathrm{a}}$ & $7.5^{\mathrm{a}}$ \\
\hline
\end{tabular}

Sensory evaluation by 6 trained panelists. Columns with the same superscripts are not significantly different at $\mathrm{P} \leq 0.05$

Compared with sample K2, sample K3 and K4 showed higher sensory characteristic in color, flavor, taste and overall acceptability. Sample K3 had the composition of MCF 85\%, MZ 10\%, and ISP 5\%. Sample K4 had the same composition as sample $\mathrm{K} 3$, with the addition of XG $2 \%$ flour based. Sample K4 showed better acceptance than sample K3 in color, flavor, taste and overall acceptability. The addition of xanthan gum was proved to improve sensory characteristic of kastengel cookies, especially in color, flavor, taste and overall acceptability.

The result of the sensory evaluation showed that the use of composite flour in kastengel cookies production resulted in cookies having more acceptable sensory characteristics than that of the $100 \%$ mocaf cookies. The blend of MCF $85 \%, \mathrm{MZ}$ $10 \%$, ISP $5 \%$ and XG $2 \%$ flour based resulted in the highest sensory characteristic among the gluten-free samples.

\section{CONCLUSION}

The composite flour based on mocaf was used to produce various cookies popular in Indonesia, such as choco-chips, nastar and kastengel cookie. The composite flour resulted in the most acceptable sensory characteristics was as follow. Choco-chips cookies were made from MCF $80 \%$ and RF $20 \%$. Nastar cookies were produced from the blend of MCF $75 \%$, RF 20\%, ISP 5\%, and XG 2\% flour based. Kastengel cookies were prepared from MCF 85\%, MF 10\%, ISP 5\%, and XG 2\% flour based. The composite flour based on mocaf is promising to replace wheat flour in the production of these cookies. The incorporation of improver such as isolated soy protein and hydrocolloids (xanthan gum or guar gum) to mocaf-based composite flour is further needed for sensory and physical evaluation.

\section{ACKNOWLEDGMENT}

This research was kindly funded by Penelitian Produk Terapan research grant from Ministry of Research, Technology and Higher Education, Republic of Indonesia.

\section{REFERENCES}

[1] A. Bala, K. Gul, and C.S. Riar, "Functional and sensory properties of cookies prepared from wheat flour supplemented with cassava and water chestnut flours," Cogent Food \& Agriculture, 2015, 1: 1019815

[2] B. Lake, and M. Water-Worth, Cereal and Cereal Products In: Food and Nutrition, Mill and Brown (Eds) will Alman and Sons Ltd., London, 1980, pp 205.

[3] W. Gisslen, Professional Baking, 6th ed., John Wiley \& Sons Inc., 2013, pp 484-485.

[4] H. Rosling, Cassava toxicity and Food Security: a review of health effects of cyanide exposure from cassava and of ways to prevent these effects, Report to the African Household Children's Fund (UNICEF), International Child Health Unit Uppsala University, Uppsala Sweden, 1987, pp 40

[5] Statistic Indonesia, Viewed July 31, 2017, https://www.bps.go.id/ linkTableDinamis/view/id/880, 2015.

[6] S. Sarabhai, D. Indrani, M. Vijaykrishnaraj, Milind, V.A. Kumar, and P. Prabhasankar, "Effect of protein concentrates, emulsifiers on textural and sensory characteristics of gluten free cookies and its immunochemical validation," J. Food Sci. Technol., 2015, 52(6):37633772 .

[7] N.A.A. Aziah, M.A.Y. Noor, and L.H. Ho, "Physicochemical and organoleptic properties of cookies incorporated with legume flour," International Food Research Journal, 2012, 19(4):1539-1543. 